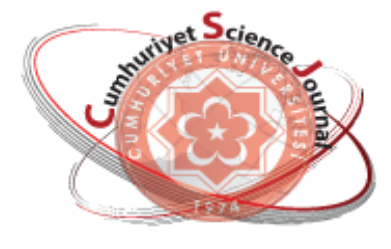

e-ISSN: 2587-246X

ISSN: $2587-2680$

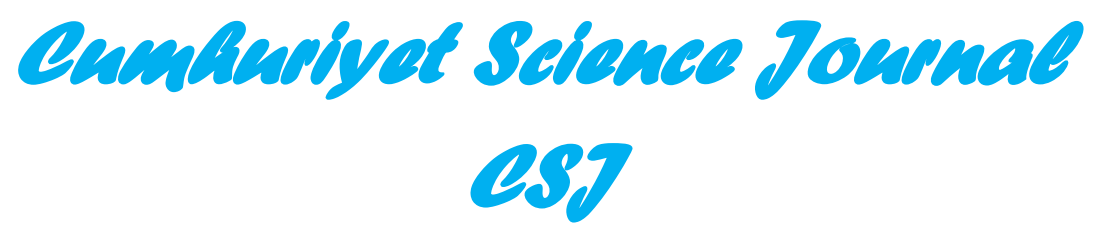

Cumhuriyet Sci. J., Vol.39-2(2018) 550-556

\title{
The Effect of Different Tread Profiles on Pullout Strength of Glass Fiber Reinforced Polymer Composite Materials
}

\author{
Engin UNAL \\ Firat University, Faculty of Technology, Department of Mechanical Engineering, Elazığ, TURKEY \\ Received: 07.05.2017; Accepted: 31.05.2018 \\ http://dx.doi.org/10.17776/csj.421618
}

\begin{abstract}
Recently, the usage of polymer composite materials has been increased significantly. Glass fiber reinforced polymer (GFRP) composite materials are preferred for different areas such as aviation, railway, energy, defense and so on due to their high thermal and tensile strength. The most common methods for joining composite machine parts are bolts and rivets, etc. In this study, Pullout tests were performed with metric, knuckle, buttress, trapezoid and square profile screws to determine the effect of different screw threads on the pullout force. The bolts were taken to have a diameter of $16 \mathrm{~mm}$ and feed of $2 \mathrm{~mm}$. In addition, a finite element model was created for determining the von-Mises equivalent stresses and total deformation. The metric thread profile gave the best results both in FEA and in experimental studies. The numerical and experimental results were in a good agreement could be concluded.
\end{abstract}

Keywords: Thread Profiles, Pullout Strength, Glass Fiber Reinforced Polymer, GFRP, Bolt.

\section{Cam Elyaf Takviyeli Polimer Kompozit Malzemelerde Farklı Vida Profillerinin Sıyırma Kuvveti Üzerine Etkisi}

Özet: Son zamanlarda polimer kompozit malzemelerin kullanımı önemli ölçüde artmıştır. Cam elyaf takviyeli polimer (CETP) kompozit malzemeler, yüksek termal ve çekme dayanımlarından ötürü havacılık, demiryolu, enerji, savunma ve bunun gibi farklı alanlarda tercih edilmektedir. Kompozit makine parçalarının birleştirilmesi için kullanılan en yaygın yöntem cıvata, perçin vb. elemanlar ile birleştirme işlemleridir. Bu çalışmada farklı vida dişlerinin sıyırma kuvvetine etkisini belirlemek amacıyla metrik, yuvarlak, testere, trapez ve kare profilli vidalarla sıyırma testi gerçekleştirilmiştir. Cıvataların çapları $16 \mathrm{~mm}$ ve adımları $2 \mathrm{~mm}$ sabit olacak şekilde alınmıştır. Ayrıca sonlu elemanlar modeli oluşturularak, von-Misess eşdeğer gerilmeleri ve toplam deformasyon miktarları hesaplanmıştır. Sıyırma kuvveti test ve analiz sonuçlarında metrik diş profiline sahip vidanın daha iyi olduğu saptanmıştır. Sayısal ve deneysel sonuçların iyi bir uyum içerisinde olduğu görülmektedir.

Anahtar Kelimeler: Vida Profilleri, Siyırma kuvveti, Cam Elyaf Takviyeli Polimer, CETP, Civata.

\section{INTRODUCTION}

Fiber reinforced plastics have been widely used for manufacturing aircraft and spacecraft structural parts because of their particular mechanical and physical properties such as high specific strength and high specific stiffness. Another relevant application for fiber reinforced polymeric composites (especially glass fiber reinforced plastics) is in the electronic industry, in which they are employed for producing printed wiring boards [1]. As structural materials, it is not possible to combine composite laminates into other metal material structures[2], and combining bolt-through efficiency and quality is significantly dependent on the quality of the processed holes[3] . Various drilling operations a commonly used to produce riveted and bolted joints during assembly of composite laminates with other components. For rivets and bolted connections, holes must be

\footnotetext{
* Corresponding author. Email address: enginunal@firat.edu.tr

http://dergipark.gov.tr/csj $\quad$ C 2016 Faculty of Science, Cumhuriyet University
} 
drilled undamaged and precision parts to ensure high connection strength and sensitivity. However, some special characteristics of composite laminates such as nonhomogeneous, anisotropic, and highly abrasive and hard reinforced fibers, result in them difficult to machine [4]. Several undesirable damages (such as delamination, and fiber pullout) induced by drilling drastically reduce strength against fatigue, thus degrading the long-term performance of composite laminates [5-7]. A usual approach to realize such a bolted connection within FRP is the use of bonded or during the lamination process, integrated threaded metallic inserts or outserts. Although it is possible to realize screwed joints in FRP parts by using these inserts or outserts, it requires quite a lot of effort $[8,9]$.
Therefore, the aim of this study is to investigate the effects of the most effective profile on the pullout strength were investigated in screw pull tests using 5 different thread profiles and bolts.

\section{MATERIALS and METHODS}

\subsection{Experimental Methods}

In this study, the tensile test to determine the mechanical properties of GFRP composites were carried out in the Ceast Impactor according to TS EN ISO 527-4 Type 1B standards and in accordance with TS EN ISO 179-1, the Charpy notch impact test made on the ZWICK Z 250 universal drawing device. The test results are given in Table 1.

Table 1. Mechanical properties of GFRP composite material.

\begin{tabular}{ccccc}
\hline Density $\left(\mathrm{gr} / \mathrm{cm}^{3}\right)$ & E-Mod $\left(\mathrm{N} / \mathrm{mm}^{2}\right)$ & Tensile Strength $\left(\mathrm{N} / \mathrm{mm}^{2}\right)$ & \% Elongation $\varepsilon$ & Impact Strength $\left(\mathrm{kJ} / \mathrm{m}^{2}\right)$ \\
\hline 2.48 & 9749 & 144 & 1.9 & 92.53 \\
\hline
\end{tabular}

In order to determine the stripping forces of the screws with different profiles, the guides and bolts of the DIN 1.7225 refinement steel were manufactured to thread the Metric (DIN 13), Trapezoidal Thread DIN 103, Square Threads DIN 603, Buttress Thread DIN 513 and Knuckle Threads DIN 405 screws (Figure 1).

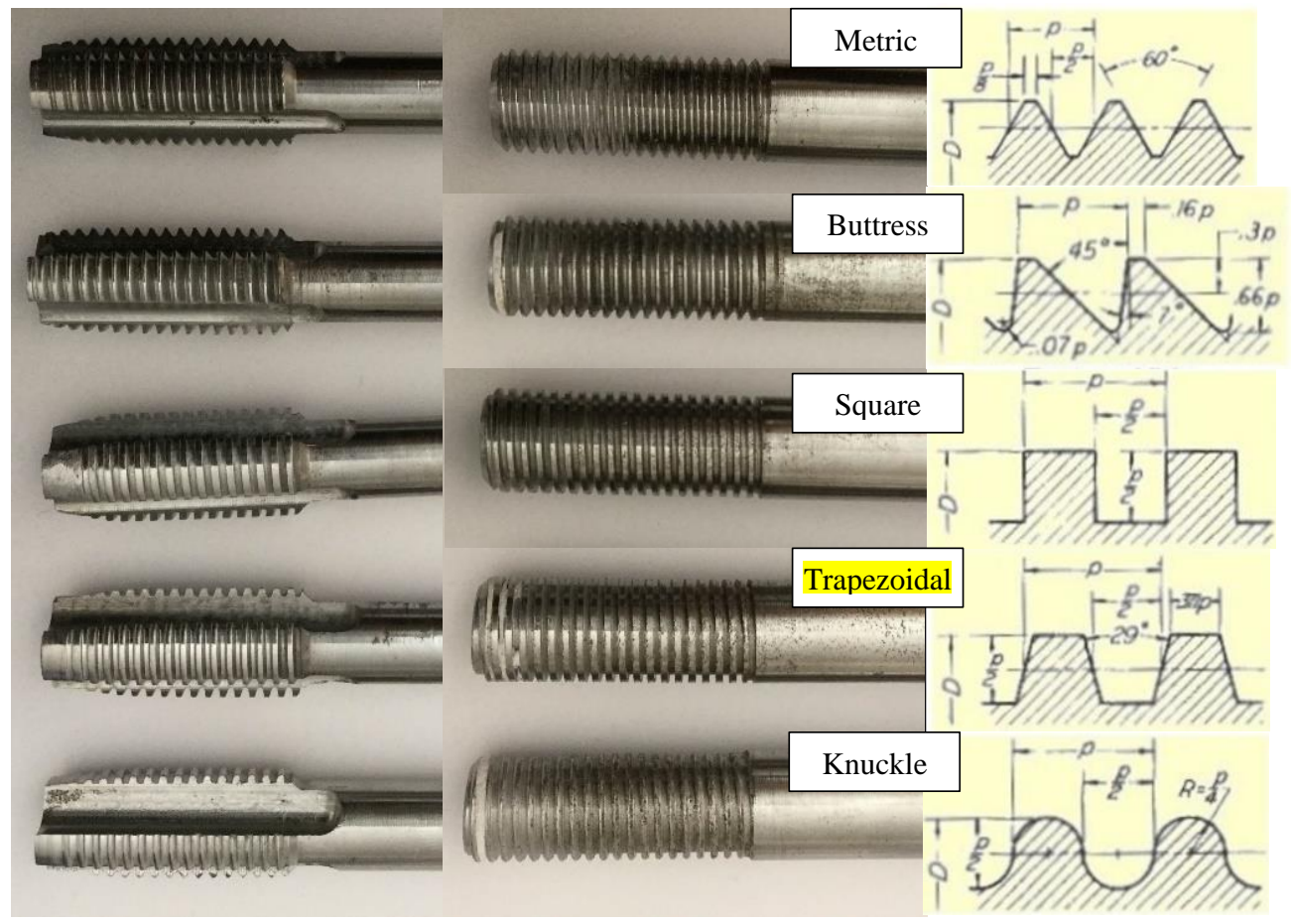

Figure 1. The guides and bolts used in experiments. 
GFRP composite material with dimensions of $340 \times 160 \times 20 \mathrm{~mm}$ was first drilled in the appropriate thread diameter measurement at the Jhonford CNC vertical machining center and then screws were tapped using the guides of each group (Figure 2). A SHIMADZU tester with a tensile capacity of $50 \mathrm{kN}$ was used to perform a pull out test at a screw pitch distance of $5 \mathrm{~mm} /$ min speed, and measurements of the pull out strengths of the screws were recorded to a computer. Each stripping test was repeated 4 times and the mean values were considered.
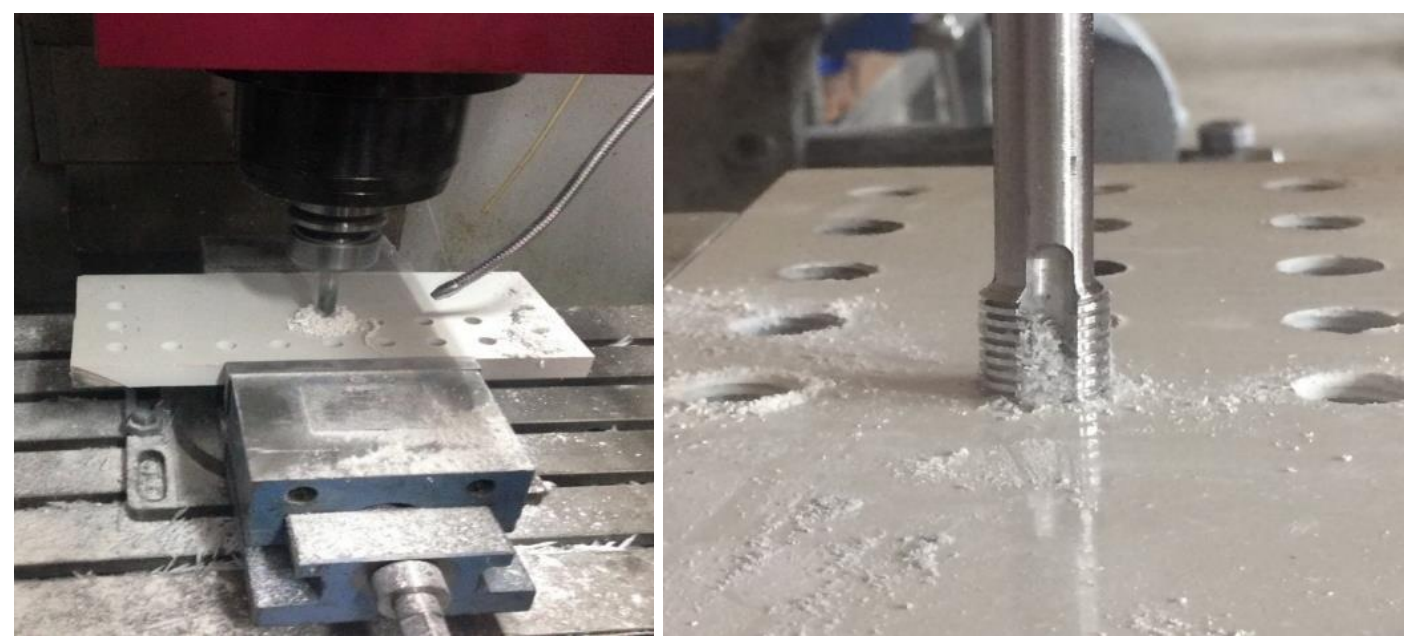

Figure 2. The drilling and tapping operation by $\mathrm{CNC}$ milling machine.

\subsection{FEM simulation method}

In this study, the pullout test was Finite Element Method (FEM) analyzed using ANSYS/Workbench software for validation purpose. In pullout simulations, a prismatic

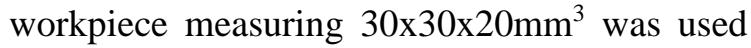
(Figure 3). The work piece material properties from the material mechanical properties for analysis was chosen (Table 1).

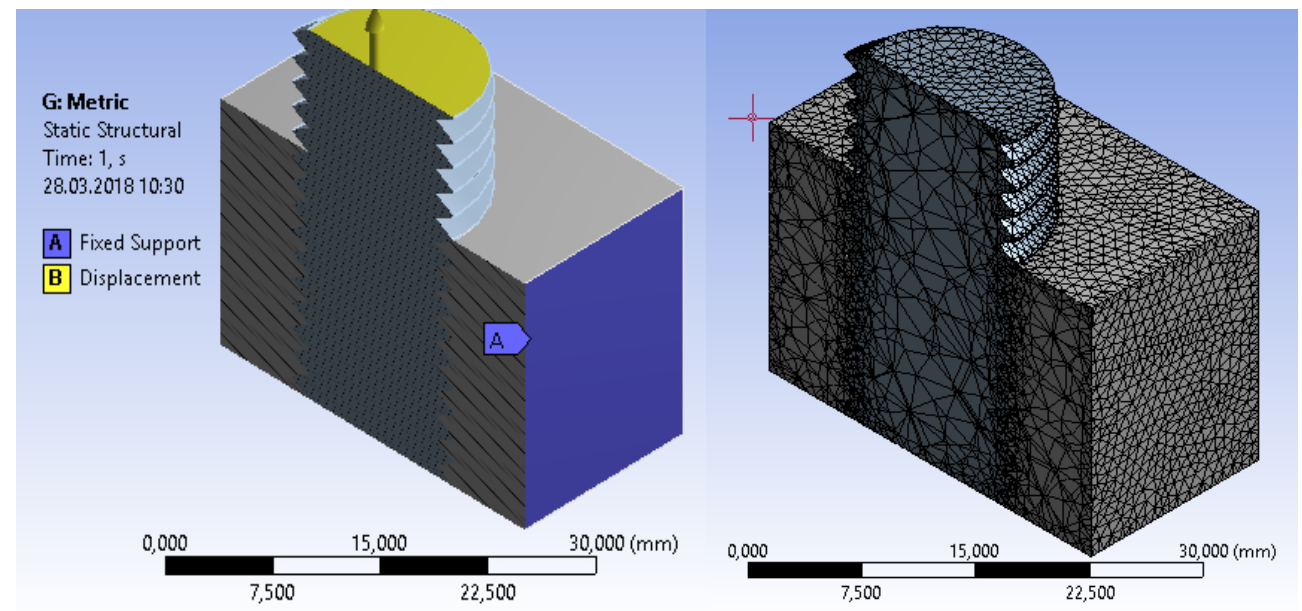

Figure 3. Boundary conditions and the mesh models of the composite nuts and bolt.

\section{RESULTS and DISCUSSION}

Glass fiber reinforced composite materials are one of the important classes of materials that change conventional engineering materials due to their excellent properties compared to metallic materials. The combination of structures is an important issue. Normally the structures are joined by drilling and riveting and or by using fasteners. The effective joining is achieved by 
using proper drilled holes in the workpiece material. Due to the thrust developed during drilling, many common problems exist. Such as fiber breakage, matrix cracking, fiber/matrix debonding, fiber pull-out, fuzzing, thermal degradation, spalling and delamination. The quality of the hole obtained in drilling are mainly depend upon thrust force. In drilling of composite laminates, the uncut thickness to withstand the drilling thrust force decreases as the drill approaches the exit plane [10].
In this context, the test results of the tests performed on the mechanical tests SHIMADZU AG-X brand $50 \mathrm{kN}$ capacity extruder are shown in Figure 4. The maximum pulling force was measured as $41.572 \mathrm{kN}$ in the metric screw profile. The minimum pull force is measured as 17.047 $\mathrm{kN}$ in the trapezoidal screw profile. The maximum pullout measured for the other thread amount is Buttress $25.792 \mathrm{kN}$, Square $18.484 \mathrm{kN}$ and Knuckle $28.67 \mathrm{kN}$.

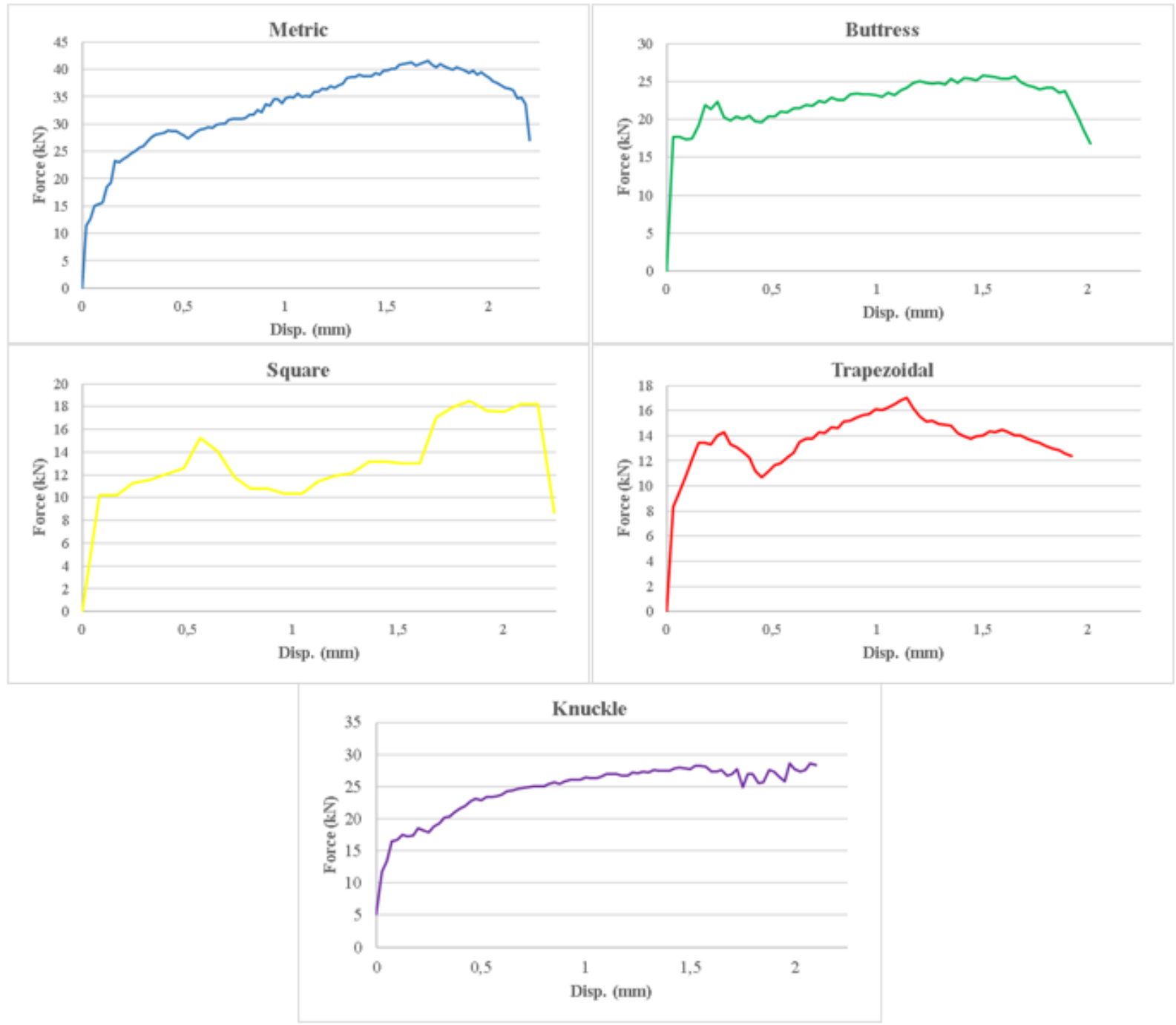

Figure 4. Pullout test results of thread profiles.

The results of the FEM analysis show that the total deformation obtained in Figure 5 and the von-misses stress results in Figure 6. In modelling results made in accordance with experimental working conditions, it has been found that for the modelled thread profiles, stresses and deformation occur in the thread of the screw. 

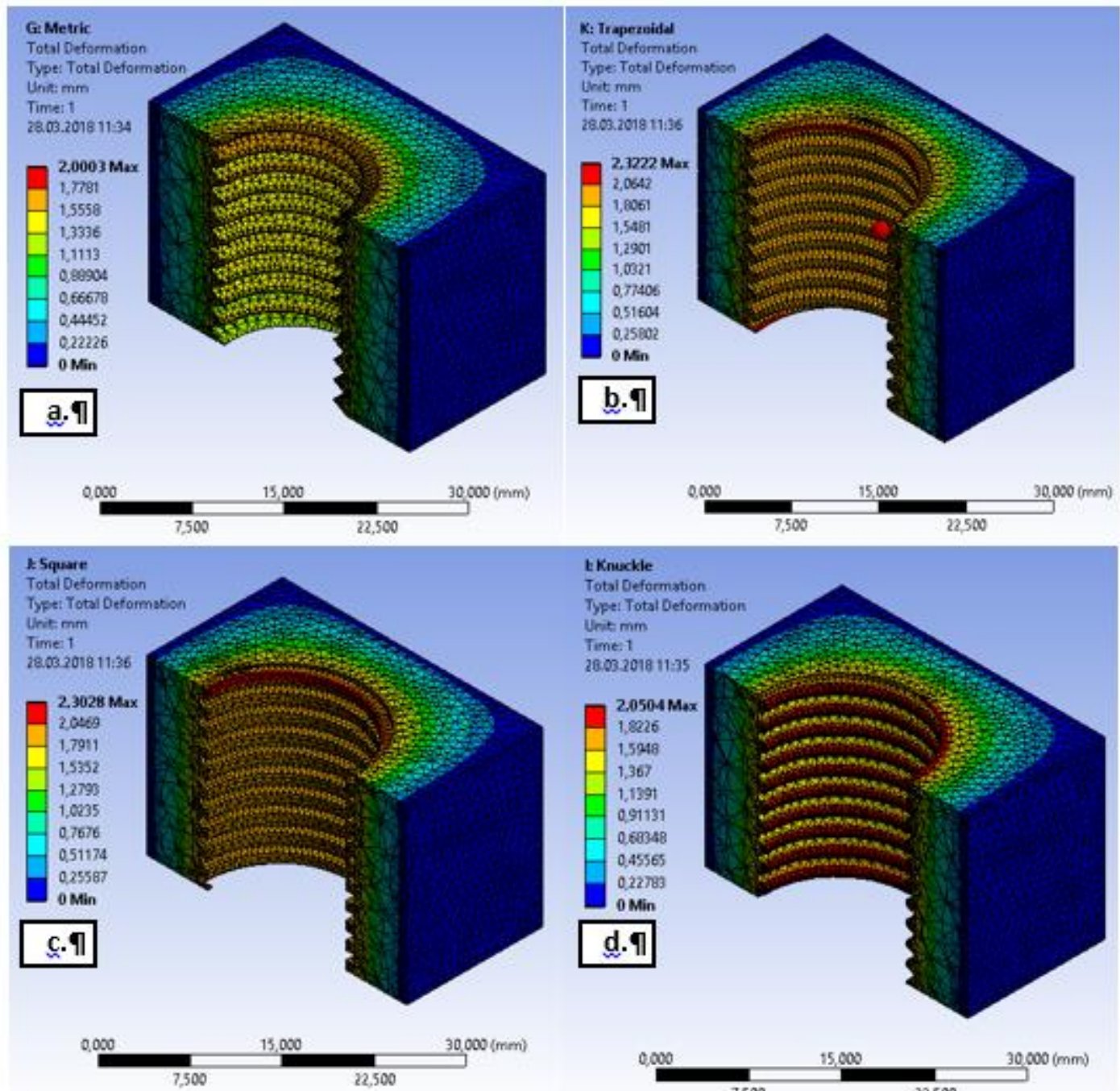

\section{t Knuckle}

EKnuckie
Totai Deformation

Type: Total Deformstion Unit mm Time: 1

$20.03201811: 35$

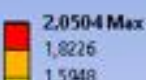

- 1,5948

(1,367

1,1997
$-1,367$

0.9131

0.68348

0.23890

0 Min

\section{d.ๆ}
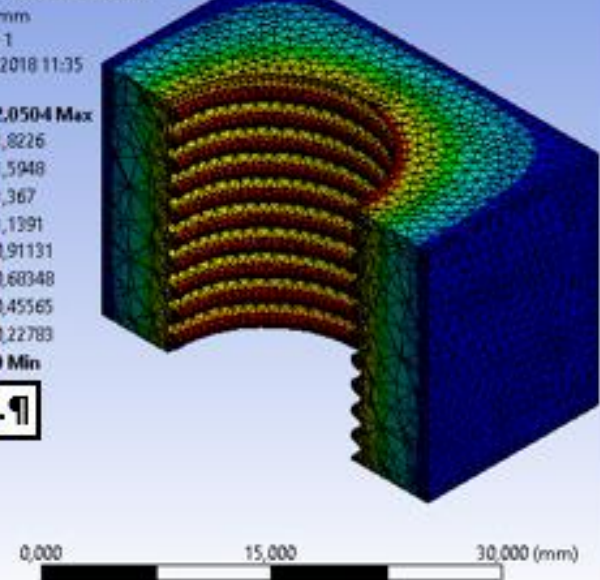

$30,000(\mathrm{~mm})$

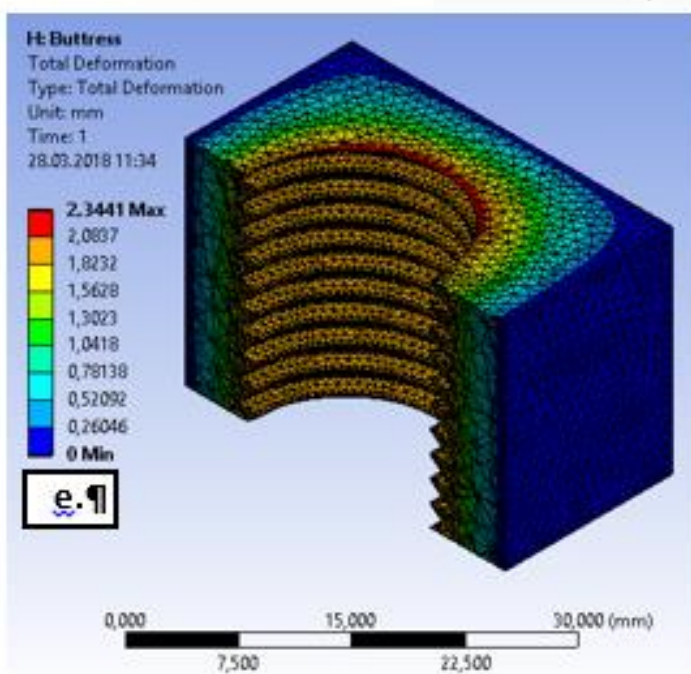

Figure 5. Total deformation analysis of ANSYS model for each thread profile (a. Metric, b. Trapezoidal, c. Square, d. Knuckle and e. Buttress). 
The resistance of the threaded studs that are axially forced by the bolt against bending and cutting are reduced by the increase of the screw profile angle. One of the most important factors on bending and cutting is the resistance against cutting the thread at the moment of pulling. The obtained value of pullout strength based on experiments are in accordance with the values reported in literature [11]. The distribution of von Mises stress around screw threads are shown in Figure 6. The location of maximum von mises stress was observed at last thread of screw. These observations are consistent with the studies in literature by Chatzistergo et al. and Varghese, V., et al. [12,13]
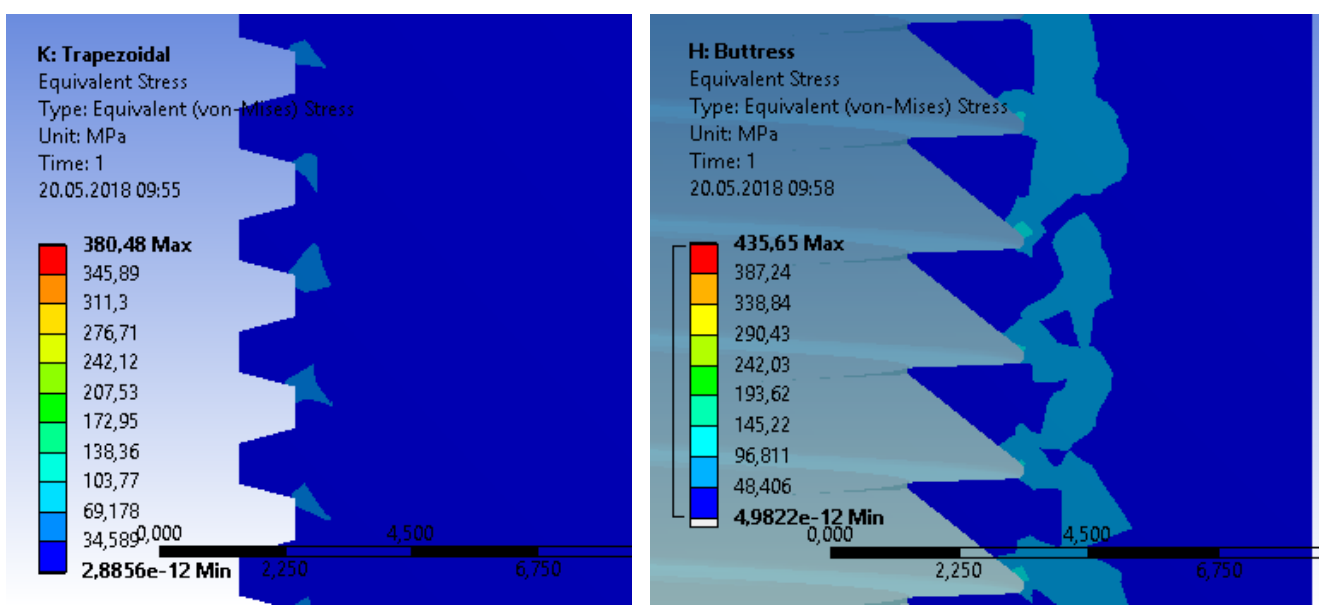

Figure 6. Equivalent (von-Mises) stress analysis of ANSYS model.

In Figure 7, comparison of stripping load according to the experimental and analytical solution for thread profile.

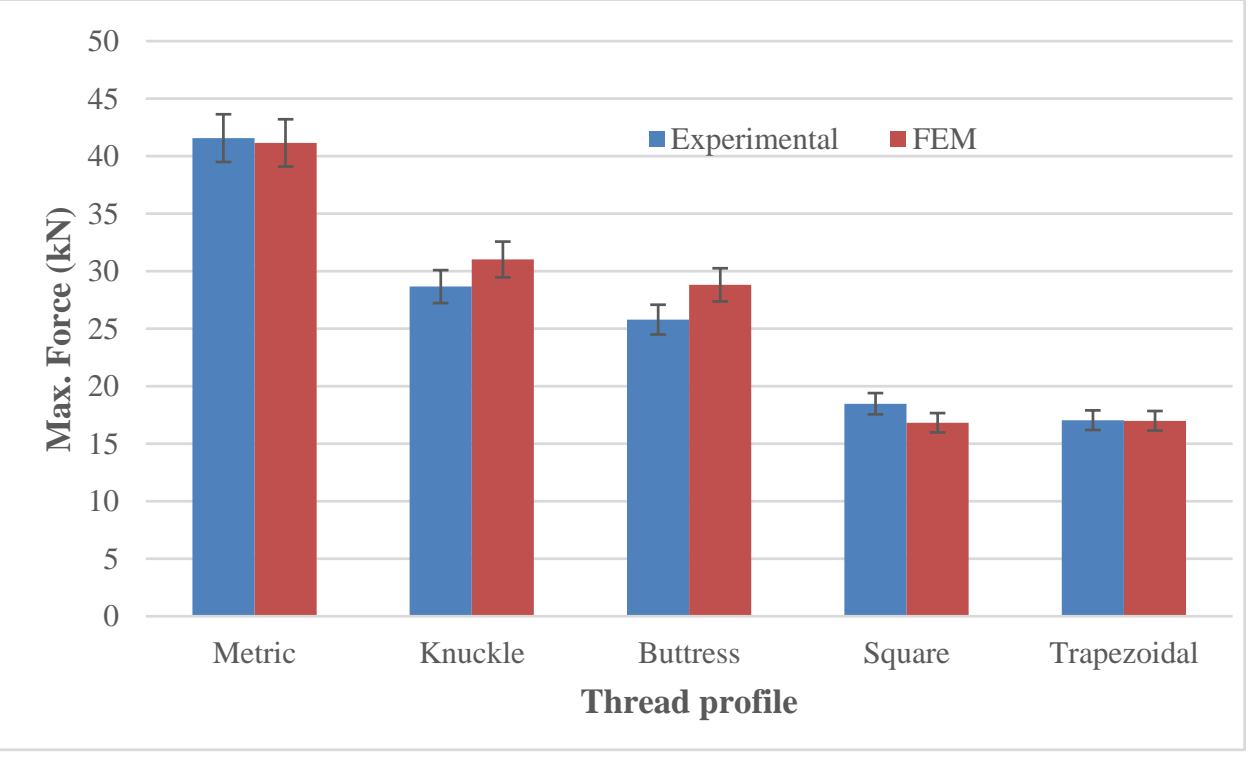

Figure 7. Comparison of pull force according to the experimental and FEM solution for thread profile.

The minimum pullout force $16.833 \mathrm{kN}$ was obtained at square thread profile as shown in Figure 7. On the other hand the maximum pullout force $41.151 \mathrm{kN}$ was existed at metric thread profile. Because of the contact area increasing, the triangular profile was indicated maximum pullout strength [14]. Experimentally found triangular thread to have higher pull out strength than square thread that observed at another study [11]. As can be seen, there are 
parallel results in our study. However the maximum deviation of the experimental via numerical solution was calculated $10.51 \%$ while buttress thread profile considered, the minimum deviation $0.32 \%$ was observed at trapezoidal thread profile. The numerical and experimental results were in a good agreement could be concluded.

\section{CONCLUSIONS}

In this paper an experimental and numerical analysis of GFRPs thread profile geometry was developed. The numerical model was validated comparing to experimental results for stepped geometry. Good accuracy was observed when predicting pullout force and deformation factor.

Through this research, the following conclusions can be summarized:

-When the pullout strength and deformation results are evaluated together, it is determined that the most effective thread profile is the metric thread profile.

- Square and Trapezoidal thread profiles have little resistance to pullout force.

- Metric thread profile should be preferred for threaded joints of GFRP composite materials.

- It has been determined that the results of the ANSYS Workbench Static Structural modeling for GFRP screw pull are in agreement with the experimental results.

\section{REFERENCES}

[1] Abrão A.M., et al., Drilling Of Fiber Reinforced Plastics: A Review, J. Mater. Process. Technol., 186 (2007), 1-3, pp. 17

[2] Hufenbach W., et al., Optimisation Of The Rivet Joints Of The CFRP Composite Material And Aluminium Alloy, J. Achiev. Mater. Manuf. Eng., 20 (2007), 1-2, pp. 119-122

[3] Singh A.P., et al., A Review Of Modeling And Control During Drilling Of Fiber Reinforced Plastic Composites, Compos. Part B Eng., 47 (2013), pp. 118-125

[4] Karimi N.Z., et al., Delamination Analysis Of Laminated Composites In Drilling And
Quasi-Static Penetration, (2015), July, pp. 19-24

[5] Phadnis V.A., et al., Finite Element Analysis Of Drilling In Carbon Fiber Reinforced Polymer Composites, J. Phys. Conf. Ser., 382 (2012), 1

[6] Mishra R., et al., Neural Network Approach For Estimating The Residual Tensile Strength After Drilling In UniDirectional Glass Fiber Reinforced Plastic Laminates, Mater. Des., 31 (2010), 6, pp. 2790-2795

[7] Karaca F., Pullout Performance Of Modified Threads In Glass Fiber Reinforced Plastic (GFRP) Composites, Mater. Test., 59 (2017), 9, pp. 779-782

[8] Zemann R., Manufacturing Of Threads Direct Into A Carbon Fibre Reinforced Polymer, Mater. Today Proc., 3 (2016), 4, pp. 1226-1229

[9] Karaca F., Investigation Of Drilling Parameters Effect On Delamination Factor In With Glass Fiber Reinforced Plastic Composites, Sci. Eng. J Firat Univ., 28 (2016), 2, pp. 23-27

[10] Rajamurugan T. V., et al., Modelling And Analysis Of Thrust Force In Drilling Of GFRP Composites Using Response Surface Methodology (RSM), Procedia Eng., 38 (2012), pp. 3757-3768

[11] Kim Y.Y., et al., Assessment Of Pedicle Screw Pullout Strength Based On Various Screw Designs And Bone Densities - An Ex Vivo Biomechanical Study, Spine J., 12 (2012), 2, pp. 164-168

[12] Chatzistergos P.E., et al., Dependence Of The Pullout Behaviour Of Pedicle Screws On The Screw-Hosting Material Relative Deformability, Int. J. Comput. Aided Eng. Technol., 5 (2013), 4, pp. 343

[13] Varghese V., et al., A Finite Element Analysis Based Sensitivity Studies On Pull Out Strength Of Pedicle Screw In Synthetic Osteoporotic Bone Models, IECBES 2016 - IEEE-EMBS Conf. Biomed. Eng. Sci., (2017), pp. 382-387

[14] Çavdar K., Öngerilmeli Cıvata Bağlarında Çözülme Problemleri, Uludağ Üniversitesi Mühendislik Fakültesi Derg., 20 (2015), 1, pp. 103-118 